NEWS

\title{
Stem cells ready for prime time
}

\section{US regulatory agency gives the go-ahead for first clinical trials of a human embryonic stem-cell treatment.}

It was a triumph of science, not politics. Yet the approval for the world's first clinical trial of a therapy generated by human embryonic stem cells, announced on 23 January, certainly seemed to be deeply political.

It was just three days into US President Barack Obama's term of office when Geron, based in Menlo Park, California, told the world that the US Food and Drug Administration (FDA) had agreed to its phase I safety study of a stem-cellderived therapy for spinal-cord injury.

But supporters say that the significance of the approval lies not in the ideology of the new administration, but in the considerable scientific hurdles that were overcome in reaching this milestone.

"There was a lot of scepticism as to whether we could reliably reproduce these manufactured products at levels of purity and identity sufficient to even allow the FDA to allow a phase I clinical trial," says Michael West, who founded Geron in 1990 and is now chief executive of BioTime in Alameda, California.

Geron, he says, "has convinced the FDA that those cells could be manufactured reliably enough for at least the first clinical trials. That is a milestone. A lot of the critics said it would be $30-50$ years before we got there."

\section{Financial benefit}

The announcement boosted the price of shares in the company, which has an extensive patent portfolio relating to embryonic stem-cell research. As of 26 January, they were trading at US $\$ 8.15$ a share - up 56\% from the day before the announcement.

In the trial, up to ten individuals who have been left paralysed after spinal-cord injury will be injected at the point of injury with stem-cell-derived precursors of oligodendrocytes, which are key supportive cells in the central nervous system. The treatments will start within 7-14 days of their injury. The company hopes that the cells will lay down sheaths of myelin - an insulator essential for conducting nerve impulses - around injured neurons, as well as stimulating nerve cells to regenerate. The cells have demonstrated both capabilities in animals (H. Keirstead et al. J. Neurosci. 25, 4694-4705; 2005).

Geron says that it expects to begin enrolment early this summer at up to seven US medical centres. In a conference call with analysts and reporters, the firm's president and chief executive Thomas Okarma said that the trial "marks the dawn of a new era in medical therapeutics. This approach is one that reaches beyond pills and scalpels to achieve a new level of healing."

Geron's 22,000-page FDA application was first submitted in March 2008, at a time when President George W. Bush had placed tight restrictions on federal funding for embryonic stem-cell research. Although Obama has promised to reverse those restrictions, the company and the FDA deny that any politics were at play in the timing of the announcement.

"Science drives our decisionmaking," says Karen Riley, an FDA spokeswoman. "Political considerations have no role in

this process." Riley adds that the process was prolonged by the time it took Geron to respond to additional questions the FDA asked the company last spring after receiving the application. Okarma says that the application included data from more than 24 studies, involving nearly 2,000 animals with injured spinal cords and requiring the production and injection of more than 5 billion cells.

Indeed, the Geron cells come from one of

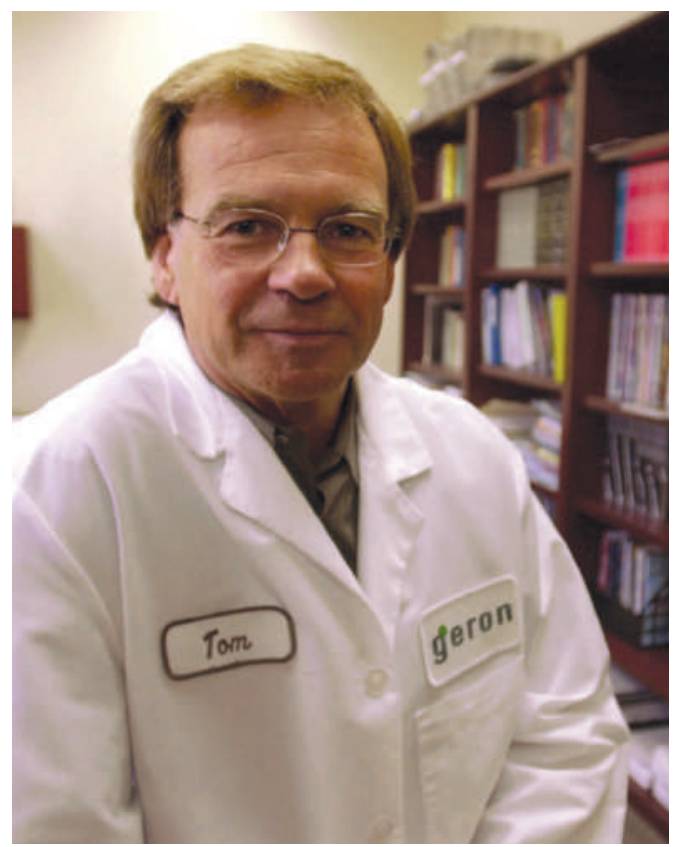

Thomas Okarma is keen to start Geron's stem-cell trial. a score of lines approved for federal funding under the Bush policy.

Groups opposing such research say that the trial's risks include the growth of tumours. "The ethical concerns include both using human embryos for the experiment as the source material, but also concern for the patient," says David Prentice, senior fellow for life sciences at the Family Research Council, a Christian advocacy group in Washington DC. "This is not a life-threatening condition," he says. "Are you actually going to be shortening the patient's life?" He cites a 2006 study in which some neural support cells - derived from human embryonic stem cells - reverted to undifferentiated growth when injected in rat models of Parkinson's disease (N. S. Roy. et al. Nature Med. 12, 1259-1268; 2006).

\section{Not perfect, but timely}

Supporters of stem-cell research have praised the FDA approval, saying that there is no 'perfect' trial with which to begin. "What I care about, what investors care about, what people who are debilitated care about, is something that can happen in the near future - not a perfect product two generations from now," says Steve Brozak, president of investment company WBB Securities in Westfield, New Jersey. Brozak has tracked stem-cell research since James

Thomson, a researcher at the University of Wisconsin in Madison, published his work on the first successful isolation of human embryonic stem-cell lines in 1998.

Other advocates say the trial should not become a test case on which the fortunes of the entire field rise or fall. "This is a trial of one particular application, not a trial of all embryonic stem cells," says Sean Tipton, immediate past-president of the Coalition for the Advancement of Medical Research in Washington DC.

Geron is a big fish in what is currently a very small pond. The other high-profile company in the field, Advanced Cell Technology in Los Angeles, California, was recently on the brink of bankruptcy. And Novocell in San Diego, is working to develop human embryonic stem cells into pancreatic $\beta$-cells, which produce insulin. Although diabetes provides a huge treatment target, Novocell's project is daunting because of the technical challenges involved in producing $\beta$-cells that safely mediate blood-sugar levels.

Meredith Wadman 